Marquette University

e-Publications@Marquette

Biological Sciences Faculty Research and

Publications

Biological Sciences, Department of

$2-2014$

\title{
Successful Treatment of an MTBE-impacted Aquifer Using a Bioreactor Self-colonized by Native Aquifer Bacteria
}

Kristin A. Hicks

University of California - Davis

Radomir Schmidt

University of California - Davis

Michael G. Nickelsen

Susan L. Boyle

Jeffrey M. Baker

See next page for additional authors

Follow this and additional works at: https://epublications.marquette.edu/bio_fac

Part of the Biology Commons

Recommended Citation

Hicks, Kristin A.; Schmidt, Radomir; Nickelsen, Michael G.; Boyle, Susan L.; Baker, Jeffrey M.; Tornatore, Paul M.; Hristova, Krassimira R.; and Scow, Kate M., "Successful Treatment of an MTBE-impacted Aquifer Using a Bioreactor Self-colonized by Native Aquifer Bacteria" (2014). Biological Sciences Faculty Research and Publications. 141.

https://epublications.marquette.edu/bio_fac/141 


\section{Authors}

Kristin A. Hicks, Radomir Schmidt, Michael G. Nickelsen, Susan L. Boyle, Jeffrey M. Baker, Paul M.

Tornatore, Krassimira R. Hristova, and Kate M. Scow 


\title{
Successful treatment of an MTBE-impacted aquifer using a bioreactor self-colonized by native aquifer bacteria
}

\author{
Kristin A. Hicks, \\ Department of Land, Air and Water Resources, University of California, One Shields Ave, Davis, \\ CA 95616, USA
}

Radomir Schmidt,

Department of Land, Air and Water Resources, University of California, One Shields Ave, Davis, CA 95616, USA

Michael G. Nickelsen,

Haley \& Aldrich, Inc., 200 Town Centre Drive, Suite 2, Rochester, NY 14623, USA

Susan L. Boyle,

Haley \& Aldrich, Inc., 200 Town Centre Drive, Suite 2, Rochester, NY 14623, USA

Jeffrey M. Baker,

Tesoro Companies, Inc., Auburn, WA 98001-9540, USA

Paul M. Tornatore,

Haley \& Aldrich, Inc., 200 Town Centre Drive, Suite 2, Rochester, NY 14623, USA

Krassimira R. Hristova, and

Department of Land, Air and Water Resources, University of California, One Shields Ave, Davis, CA 95616, USA; Biological Sciences Department, Marquette University, Milwaukee, WI 53233, USA

\section{Kate M. Scow}

Department of Land, Air and Water Resources, University of California, One Shields Ave, Davis, CA 95616, USA

Radomir Schmidt: radschmidt@ucdavis.edu

\section{Abstract}

A field-scale fixed bed bioreactor was used to successfully treat an MTBE-contaminated aquifer in North Hollywood, CA without requiring inoculation with introduced bacteria. Native bacteria from the MTBE-impacted aquifer rapidly colonized the bioreactor, entering the bioreactor in the contaminated groundwater pumped from the site, and biodegraded MTBE with greater than $99 \%$ removal efficiency. DNA sequencing of the 16S rRNA gene identified MTBE-degrading bacteria Methylibium petroleiphilum in the bioreactor. Quantitative PCR showed M. petroleiphilum enriched by three orders of magnitude in the bioreactor above densities pre-existing in the groundwater. Because treatment was carried out by indigenous rather than introduced organisms, regulatory approval was obtained for implementation of a full-scale bioreactor to continue treatment of the aquifer. In addition, after confirmation of MTBE removal in the bioreactor to below maximum contaminant limit levels (MCL; MTBE $=5 \mu \mathrm{g} \mathrm{L}^{-1}$ ), treated water was approved for reinjection back into the aquifer rather than requiring discharge to a water treatment system. This is the first treatment system in California to be approved for reinjection of biologically

(C) Springer Science+Business Media Dordrecht 2013

Correspondence to: Radomir Schmidt, radschmidt @ucdavis . edu. 
treated effluent into a drinking water aquifer. This study demonstrated the potential for using native microbial communities already present in the aquifer as an inoculum for ex-situ bioreactors, circumventing the need to establish non-native, non-acclimated and potentially costly inoculants. Understanding and harnessing the metabolic potential of native organisms circumvents some of the issues associated with introducing non-native organisms into drinking water aquifers, and can provide a low-cost and efficient remediation technology that can streamline future bioremediation approval processes.

\section{Keywords}

Methylibium petroleiphilum PM1; Bioreactor; MTBE; GAC; Aquifer; Groundwater

\section{Introduction}

Recent cost estimates for treatment of identified methyl tert-butyl ether (MTBE) releases place the price tag near $\$ 2$ billion (Sweet et al. 2010). Development of cost-effective field technologies for treating MTBE-impacted water supplies has played a part in bringing the price tag down from earlier cleanup estimates that ranged from \$29-85 billion (Mehta 2001). However, further improvements in field technologies for treatment of MTBEcontaminated groundwater are essential to quickly and economically address the vast number of releases currently being addressed by other means.

Ex-situ bioreactors have been used for many decades to treat industrial and municipal wastewater. However, bioreactor technologies for treatment of contaminated groundwater have only recently been applied to the treatment of MTBE. Several lab and pilot-scale MTBE treatment studies have demonstrated the potential of aerobic bioreactors inoculated with pure or mixed MTBE-degrading cultures. Several of these studies utilized the same inoculum source which consisted chiefly of mixed liquor from the Cincinnati Metropolitan Sewer District (Morrison et al. 2002; Pruden et al. 2001; Wilson et al. 2002, 2001; Zein et al. 2004, 2006), while others were enrichment cultures derived from fuel-contaminated sediment and water samples (Kharoune et al. 2001; Stringfellow and Oh 2002).

The model strain, M. petroleiphilum PM1, is one of the few well characterized MTBE degrading bacteria-its physiology has been described (Nakatsu et al. 2006; Bruns et al. 2001; Hanson et al. 1999), its genome sequenced (Kane et al. 2007) and components of its MTBE degradation pathway characterized (Hristova et al. 2007; Schmidt et al. 2008). DNA sequences of naturally occurring bacteria with $93-99 \%$ identity to $M$. petroleiphilum in their 16S rRNA gene have been identified at several MTBE-contaminated sites in California (Hristova et al. 2003; Kane et al. 2001). In an exploratory study, aerobic MTBE and TBA biodegradation was observed in groundwater and sediment microcosms from the North Hollywood site (Battaglia, personal communication) and M. petroleiphilum was identified using denaturing gradient gel electrophoresis (DGGE) and quantitative polymerase chain reaction (qPCR) (>96\% 16S rRNA gene identity; Hristova unpublished data). The presence of M. petroleiphilum at the North Hollywood site, coupled with demonstrable MTBE degradation, formed a strong rationale for exploring a self-seeded field-scale bioreactor for treating the MTBE-impacted groundwater.

The use of non-native bacterial cultures or consortia in bioreactors has a number of challenges, particularly when scale-up to field remediation is the eventual goal. Introduced organisms have to compete with native bacteria already evolved to live in an aquifer environment and the likelihood of establishment by introduced organisms is highly uncertain. For example, native toluene-degrading bacteria quickly displaced inoculated 
strains and successfully removed toluene in a lab study of a bioreactor treating toluene (Massol-Deya et al. 1997). Inoculants are usually added at very high densities and grown under nutrient and redox conditions far different from those encountered by local groundwater bacteria. Another challenge is that application to re-inject water treated by nonnative bacteria-populated bioreactor into drinking water aquifers is likely to meet strong regulatory resistance from institutions charged with water quality and drinking water protection. The possibility of contaminating the aquifer with non-native bacteria is likely to be viewed as too great a risk by the relevant authorities. In addition, the use of proprietary microbial blends can be expensive and add significant and potentially unnecessary costs to a remediation project.

The objective of this study was to investigate the potential of naturally occurring aquifer bacteria to colonize a fixed bed bioreactor and efficiently biodegrade MTBE present in the groundwater. The initial field trial tested an ex-situ, uninoculated, pilot scale, fixed bed bioreactor designed to remove the high concentration core of an MTBE plume in a North Hollywood, CA aquifer. The bioreactor was packed with granular activated carbon (GAC) as biological carrier material and amended with oxygen and nutrients. The pilot scale field study demonstrated rapid colonization of the bioreactor by native aquifer bacteria, and efficient MTBE and TBA degradation in the bioreactor. In order to assess the effectiveness of the bioreactor to create and maintain conditions suitable for microbial MTBE degraders growth and function, we characterized the population dynamics of M. petroleiphilum. As a result, at the end of the one-year field trial the California Regional Water Quality Control Board (CRWQCB) approved implementation of additional bioreactor tanks at the site. The full-scale bioreactor operated as the sole groundwater remediation activity at the site from 2005 until the system was shut down in 2008, thereby completing the off-site portion of site remediation (CRWQCB 2009). Once on-site soil vapor extraction remediation was deemed complete the entire site was closed in 2011 (CRWQCB 2011).

\section{Methods}

\section{Site background}

In the 1990s, a leaking underground fuel tank was identified and removed from a fast fuel facility in North Hollywood, CA. The site is surrounded by the North Hollywood, Whitnall and Erwin municipal drinking water well fields, that together accounted for $\sim 25 \%$ of the drinking water production of the San Fernando Valley aquifer for the years 2006-2011 (Slade 2012). A variety of active and passive measures were implemented to treat the release of petroleum hydrocarbons into the underlying aquifer. In 2004, the disconnected MTBE plume had a core concentration of $>10 \mathrm{mg} \mathrm{L}^{-1}$ and was estimated to contain 158-181 kg in mass (Fig. 3). Depth to groundwater at the North Hollywood site was over $200 \mathrm{ft}$ and was increasing due to local pumping of the aquifer. The MTBE plume occurred in the upper $30 \mathrm{ft}$ of a high permeability, anoxic, unconfined aquifer. MTBE migrated as a high concentration pulse in an approximately east-southeasterly direction at a velocity of $100 \mathrm{ft} / \mathrm{year}$, which would have brought it into contact with regional water supply wells (over 70 wells exist within a 1-1/2 mile radius) if not contained and eliminated. The site was located in a densely populated residential neighborhood in a metropolitan area, making it unamenable to a large scale conventional pump and treat approach. The groundwater containing the plume had high concentrations of major cations and anions with a $\mathrm{pH}$ ranging from 6.5 to 7.5. Concentrations of dissolved organic carbon (DOC) were low, averaging $3 \mathrm{mg} \mathrm{L}^{-1}$ (reporting limit $<0.08 \mathrm{mg} \mathrm{L}^{-1}$ ), and concentrations of total organic carbon (TOC) averaged $11 \mathrm{mg} \mathrm{L}^{-1}$ (reporting limit $<0.1 \mathrm{mg} \mathrm{L}^{-1}$ ) (for site details see [GeoTracker]). 


\section{Pilot scale bioreactor design and operation}

Groundwater pumped from the core of the plume was treated using two continuously fed primary treatment tanks (T100 and T200) packed with coconut shell-based GAC (WestatesUS Filter Corp.). Effluents from both units were combined and passed through a third (T300) GAC bed for polishing prior to discharge (Fig. 1). The data discussed here were collected during the pilot scale bioreactor operation during the first 52 weeks of operations at the site. Pilot scale bioreactor parameters are listed in Table 1.

Water fed to the primary treatment tanks was amended with a hydrogen peroxide/phosphate/ nitrate solution to increase dissolved oxygen concentrations and provide nutrients for biological growth. The feed rate was variable and was based on maintaining dissolved oxygen concentration $>5 \mathrm{mg} \mathrm{L}^{-1}$ in the combined T100/T200 effluent. Targeted dissolved oxygen concentrations were obtained by manually adjusting the hydrogen peroxide/nutrient chemical feed pump and monitored using either a clark cell-based electrode, a colorimetric field test kit or an optical-based Hach LDO probe. During week 30, an automated control loop was installed and interfaced with the chemical feed pump and LDO probe to control the hydrogen peroxide/nutrient feed pump based on real time DO measurement in the combined T100/T200 effluent.

\section{Chemical analyses}

Groundwater and process water samples were analyzed for benzene, toluene, ethylbenzene, xylene, MTBE, and TBA by a California certified laboratory (Kiff Analytical, LLC) using EPA Method 8260B with reporting limits of $0.5-5 \mu \mathrm{g} \mathrm{L}^{-1}$. $\mathrm{pH}$ was measured on site using a Multiparameter Troll 9000 (In-Situ, Inc.) equipped with a pH electrode.

\section{Bacterial enumeration}

Water samples were collected at the influent, primary tank effluent, and in the mid-bed region of the T100 and T200 primary tanks (Fig. 1). GAC samples were collected from the mid-bed region of both primary tanks. Samples were collected weekly for 6 months and monthly thereafter. Aqueous and GAC-associated bacteria were quantified by viable plate counts and by qPCR.

Viable planktonic bacteria were quantified by serial dilutions in $0.9 \%$ saline followed by spread plating on Difco R2A media (Becton, Dickinson and Co. Sparks, MD) and incubation at $27^{\circ} \mathrm{C}$ for 5 days. For qPCR, water samples $(250-500 \mathrm{~mL})$ were collected on 47 mm $0.2 \mu \mathrm{m}$ Isopore Membrane filters (Millipore Corp., Bedford, MA) using a Nalgene filter housing with a vacuum attachment. Mid-bed water samples were first passed through a 25 $\mu \mathrm{m}$ prefilter to remove GAC residues, which dramatically interfered with the DNA extraction efficiency. DNA was extracted from triplicate samples as described in (Hristova et al. 2001).

For GAC-associated bacteria, cells were first removed from the GAC material by a modification of the pyrophosphate plus sonication method (Persson et al. 2006;

Schallenberg et al. 1989; Velji and Albright 1986). Briefly, $1 \mathrm{~g}$ of GAC was added to a $9 \mathrm{~mL}$ solution of mineral salts medium (MSM) plus $0.1 \%$ sodium pyrophosphate and incubated in a $27^{\circ} \mathrm{C}$ shaker for $1 \mathrm{~h}$. The solution was sonicated for $30 \mathrm{~s}$ in a Solid State Ultrasonic FS-9 sonicator (Fisher Scientific) and decanted. An additional $9 \mathrm{~mL}$ of MSM + 0.1\% SPP solution was added to the GAC, the incubation/sonication procedure was repeated once and the two bacterial solutions combined. Viable plate counts were performed on this bacterial solution as described above for groundwater. For qPCR, the solution was first passed through a $25 \mathrm{~mm}$ filter to remove particulate GAC, collected on a $0.2 \mu \mathrm{m}$ filter, and DNA 
extractions from GAC were then performed as previously described for groundwater (Hristova et al. 2001).

Bacterial numbers are reported as colony-forming units (CFU) for plate counts and as cell numbers for qPCR and are expressed on an equivalent volumetric basis for both GAC and water samples. GAC data was converted from a mass to a volumetric basis by determining the average bulk volume of ten 1 gram samples of wet, drained GAC $\left(0.85 \mathrm{~g} \mathrm{~cm}^{-3}\right)$.

\section{Taqman real-time quantitative PCR}

Dilutions of DNA for qPCR reactions were made in autoclaved, filter-sterilized, deionized water. PCR was performed in $12.5 \mu \mathrm{L}$ volumes with MicroAmp optical 96-well reaction plates and MicroAmp optical adhesive covers using a 7300 Real Time PCR System (Applied Biosystems, Foster City, CA). Universal bacterial primers and probe targeting the $16 \mathrm{~s}$ rRNA region were used to quantify total bacterial copies in each sample (Hristova et al. 2001).

Methilibium petroleiphilum cells were enumerated by Taqman qPCR targeting the $16 \mathrm{~S}$ rRNA gene as previously described (Hristova et al. 2001). Briefly, a 113-bp product was amplified with primers $963 \mathrm{~F}$ and $1076 \mathrm{R}$ and a fluorogenic probe 1030T labeled with a reporter dye-FAM (6-carboxyfluorescein) - at the $5^{\prime}$ end and a quencher-TAMRA (6carboxytetra-methylrhodamine) - at the $3^{\prime}$ end. For complete description of Taqman qPCR reaction conditions and data analyses, see Hristova et al. (2001).

\section{Results}

\section{Bioreactor performance}

Influent MTBE concentrations and the mass loading rate per bed were $14 \mathrm{mg} \mathrm{L}^{-1}$ and $750 \mathrm{~g}$ day $^{-1}$, respectively, at startup, and decreased to $800 \mu \mathrm{g} \mathrm{L}^{-1}$ and $50 \mathrm{~g} \mathrm{day}^{-1}$ (Fig. 2) by the 52 nd week of treatment as the aquifer was remediated. Using the Freundlich equation and an isotherm from representative GAC material, breakthrough of MTBE in the absence of biological activity was estimated to occur at day 1 .

Percent removals of MTBE in the primary treatment beds were highly efficient and similar to each other (Fig. 2; Table 2). By week 17, the system had reached steady state removal efficiencies of 99.2 and $99.5 \%$ in Tanks 100 and 200, respectively, with a final postpolishing bed removal efficiency of $>99.9 \%$. The removal efficiency of T100 was slightly lower than that of T200 due to an operator error in week 21 that created anaerobic conditions in the T100 bed for weeks 21 through 24.

Over the 52-week pilot study period, tanks T100 and T200 treated $57.9 \mathrm{~kg}$ and $57.3 \mathrm{~kg}$ of MTBE, respectively. During that same time period, the system treated $28,400 \mathrm{~m}^{3}$ of MTBEcontaminated water and significantly reduced the mass and volume of the original plume (Figs. 3, 4). The maximum MTBE removal rates attained by the T100 and T200 tanks were 391 and $333 \mathrm{mg}$ MTBE per $\mathrm{cm}^{3}$ bulk tank volume per day respectively. As the contaminant plume shrank and the influent MTBE concentrations decreased, the system continued to efficiently treat even at MTBE loading rates below 1,000 $\mu \mathrm{g} \mathrm{L}^{-1}$.

The bioreactor was scaled up by adding three additional tanks in 2005 and continued to operate into 2008. The full scale bioreactor operated at a maximum flow rate of $151 \mathrm{~L}$ $\mathrm{min}^{-1}$, removed a total of $\sim 134 \mathrm{~kg}$ of MTBE, and extracted $164,000 \mathrm{~m}^{3}$ of water, with more than $113,000 \mathrm{~m}^{3}$ being re-injected into the aquifer via MW-25. Additionally, the bioreactor system never experienced any pressure buildup resulting from bed clogging, and never required GAC change-out. Throughout its 4 years of operation, the MTBE concentration 
declined from 5,800 $\mu \mathrm{g} \mathrm{L}^{-1}$ to non-detect (ND) $\left(<1.0 \mu \mathrm{g} \mathrm{L}^{-1}\right)$ in MW-15, 5,900 $\mu \mathrm{g} \mathrm{L}^{-1}$ to $\mathrm{ND}\left(<1.0 \mu \mathrm{g} \mathrm{L}^{-1}\right)$ in MW-19, and $410 \mu \mathrm{g} \mathrm{L}^{-1}$ to ND $\left(<1.0 \mu \mathrm{g} \mathrm{L}^{-1}\right)$ in MW-19R (see Figs. 3, 4; GeoTracker 2012). In August 2008 the bioreactor was permanently shut down and decommissioned in July 2009.

\section{Bacterial densities}

Bacterial densities in the influent averaged $4.1 \times 10^{3} \mathrm{CFU} \mathrm{ml}^{-1}$ by viable plate count and 3.1 $\times 10^{5}$ cells $\mathrm{ml}^{-1}$ by qPCR (Table 3 ). The influent and effluent bacteria densities were similar, suggesting that the bioreactor effectively retained biomass. Based on both plate counts and qPCR, effluent bacterial densities $\left(1.5 \times 10^{4} \mathrm{CFU} \mathrm{ml}^{-1}\right.$ and $\left.8.0 \times 10^{5} \mathrm{cells} \mathrm{ml}^{-1}\right)$ were within an order of magnitude of influent densities. Colonization of the bioreactor by native aquifer bacteria occurred rapidly with attached bacterial densities reaching $10^{7}$ cells $\mathrm{cm}^{-3}$ (plate counts and qPCR) by the time of the first biomass sampling on day 6 (Fig. 5). Steady state ( $>17$ weeks) bacterial densities for the two treatment tanks were similar, both by plate counts and qPCR (Table 3 ). Steady state densities of attached bacteria averaged 4.9 $\times 10^{7}$ by plate counts and $9.4 \times 10^{7}$ by qPCR. Aqueous bacteria averaged $2.7 \times 10^{6} \mathrm{CFU}$ $\mathrm{ml}^{-1}$ by plate counts and $9.5 \times 10^{6}$ cells ml ${ }^{-1}$ by qPCR. Aqueous bacteria inside the tanks numbered approximately one order of magnitude lower than attached bacteria by both detection methods and for both tanks.

\section{M. petroleiphilum densities by qPCR}

M. petroleiphilum was detected by qPCR in the influent and effluent at each sample date although the densities were highly variable. Densities of GAC-associated M. petroleiphilum were $3.7 \times 10^{4}$ and $6.8 \times 10^{4}$ cells $\mathrm{cm}^{-3}$ in tanks 100 and 200, respectively, at day 6 (Fig. 6). These densities increased by three orders of magnitude over the year of the study, reaching $1.7 \times 10^{7}$ (T100) and $3.1 \times 10^{7}$ cells cm$~_{-3}$ (T200). The percentage of M. petroleiphilum making up the total population of bacteria also increased over this time. At week $1, M$. petroleiphilum represented $0.05 \%$ of total bacteria in T100 and $11 \%$ at week 32. In T200, M. petroleiphilum represented $0.23 \%$ of total bacteria at week 1 and $30 \%$ at week 32 . Conversely, M. petroleiphilum cell numbers in the aqueous phase within both tanks did not increase significantly over the course of the study and averaged $3.1 \times 10^{4}$ and $6.1 \times 10^{4}$ cells $\mathrm{ml}^{-1}$ in the two primary tanks. M. petroleiphilum densities increased steadily during the early phases of the operation when MTBE concentrations were high before leveling off after week 20 (Fig. 6). This leveling off corresponded to influent MTBE concentration dropping close to $2,000 \mu \mathrm{g} \mathrm{L}-1$ and remaining close to this level for the rest of the study (Fig. 2).

\section{Operational upset}

Both total bacterial biomass and effluent MTBE appeared to reach steady state as early as week 1 . At week 5, a disruption in the operation of the system occurred during an aquifer pumping test and MTBE concentrations rose to detectable levels in the effluent of the primary tanks (Figs. 2, 5). The concentration of effluent MTBE reached a maximum of $\sim 1.5$ $\mathrm{mg} \mathrm{L}^{-1}$ in week 10 and then decreased until the onset of steady state removal at week 17 . The operational upset coincided with a large spike in hydrogen peroxide addition (100 mg $\mathrm{L}^{-1}$ ), which was due to operator error, and was followed by a significant drop in total biomass. The bacteriocidal properties of hydrogen peroxide are well established (Bayliss and Waites 1980; Christensen et al. 1990) which likely explains the sudden loss of biomass. The sharp decrease in total bacteria at week 5 was evident, by both plate counts and qPCR, in the two treatment tanks, and in both aqueous and attached phases (Figs. 5, 6). The strong positive correlation observed between biomass and MTBE removal provided evidence that MTBE degradation was biologically mediated. While the drop in biomass was observable by qPCR, it was more evident in the plate counts. Presumably, because plate counts report live 
bacteria while qPCR quantifies copies of DNA sequences (i.e. both live and dead bacteria), the plate counts were a more sensitive indicator of live bacterial populations.

A second, shorter hydrogen peroxide spike occurred at week 9 and likely contributed to a smaller loss of biomass and drop in system performance at that same time. Both biomass and bioreactor performance had completely recovered from the first upset by week 17 and the highest spike in MTBE at final discharge never exceeded the sewer discharge limit $\left(1,000 \mu \mathrm{g} \mathrm{L}^{-1}\right)$. At week 30, a control loop was installed to automate the influent chemical feed rate according to the $5 \mathrm{mg} \mathrm{L}^{-1}$ target effluent DO concentration and both biomass and bioreactor performance remained stable thereafter.

\section{Detection and removal of non-target co-contaminants}

Influent concentrations of the first metabolic intermediate of MTBE degradation-tert-butyl alcohol (TBA) —averaged $54.7 \mu \mathrm{g} \mathrm{L}^{-1}$, with a median concentration of $23.5 \mu \mathrm{g} \mathrm{L}^{-1}$, and decreased over the year of pilot scale study. Effluent TBA concentrations from tanks T100 and T200 were very low and infrequently detected with averages of 15.2 and $17.3 \mu \mathrm{g} \mathrm{L}^{-1}$, respectively (detection limit $5 \mu \mathrm{g} \mathrm{L}^{-1}$ ). Out of 90 sample dates, TBA was detected five times each in T100 and T200 effluents. No TBA was detected in T100 after week 18 or in T200 after week 8 .

Influent concentrations of benzene, toluene, ethyl-benzene, and xylene (BTEX) were low and infrequently detected. Of 110 samples, toluene was detected once $\left(5.4 \mu \mathrm{g} \mathrm{L}^{-1}\right)$, ethylbenzene once $\left(14 \mu \mathrm{g} \mathrm{L}^{-1}\right)$, and xylene thrice $\left(15,5\right.$, and $\left.5.4 \mu \mathrm{g} \mathrm{L}^{-1}\right)$. Benzene was the most frequently detected BTEX compound in the influent with a total of six detections averaging $7.1 \mu \mathrm{g} \mathrm{L}^{-1}$ (>0.5 $\mu \mathrm{g} \mathrm{L}^{-1}$ detection limit). BTEX compounds were not detected in effluents from either of the primary beds, with the exception of one detection of toluene in $\mathrm{T} 100$ in week $7\left(0.66 \mu \mathrm{g} \mathrm{L}^{-1}\right)$. Low concentrations of chlorinated compounds (primarily trichloroethene (TCE) $\backslash 10 \mu \mathrm{g} \mathrm{L}^{-1}$ and tetrachloroethene (PCE) $<5 \mu \mathrm{g} \mathrm{L}^{-1}$ ) were also present in the influent ground water. Their presence had no apparent effect on MTBE degradation.

\section{Discussion}

The North Hollywood bioreactor treated over 7.5 million gallons of site groundwater during the 52-week period of operation during the field trial. The two primary GAC beds were rapidly populated, without requiring inoculation, by MTBE-degrading microorganisms originating from the on-site ground-water. The bioreactor effluent successfully met both California primary and secondary MCLs for MTBE and TBA while significantly reducing contaminant mass present in the core of the plume. As a result, the CRWQCB approved scale-up of the GAC bioreactor after $\sim 1$ year of operation. Additional and larger GAC vessels were installed between May 2005 and August 2005 to increase system capacity and ensure continuous MTBE degradation. The full-scale bioreactor operated as the sole groundwater remediation technology on the disconnected off-site MTBE plume from 2005 to 2008 and treated/reinjected over 39 million gallons back into the drinking water supply (on-site soil vapor extraction was mitigating impacts to on-site groundwater) (CRWQCB 2009, 2011).

As well as monitoring the physico-chemical parameters of the bioreactor treatment system, we characterized the population dynamics of, M. petroleiphilum, a potential member of the MTBE degradation com munity. Cells of M. petroleiphilum attached to the GAC in the bioreactor increased three orders of magnitude over the course of the study and the percentage they made up of the total bacterial density also increased. While total bacterial numbers remained stable throughout steady state operation, M. petroleiphilum increased 
from $10^{4}$ to a maximum of $10^{7}$ cells $\mathrm{cm}^{-3}$, at which point it made up $33 \%$ of the total attached bacteria. This increase of attached $M$. petroleiphilum cell numbers suggested that the organism may have played a role in MTBE degradation in the bioreactor. In previous studies, MTBE mineralization has been linked to enrichment of native bacteria 96-99\% identical to M. petroleiphilum strain PM1 at an oxygen amended field site also located in southern California (Hristova et al. 2003), in microcosms constructed from MTBEcontaminated aquifer sediments (Kane et al. 2001), and in a GAC-based, bench-scale MTBE bioreactor (Pruden et al. 2003). Immobilized M. petroleiphilum strain PM1 cells effectively removed $96 \%$ of MTBE in a continuous-mode, fixed-bed bioreactor (Cheng et al. 2011). ${ }^{13}$ C labeled DNA with $99.7 \%$ identity to $M$. petroleiphilum strain PM1 16S rRNA gene, as well as identities to genes in the proposed PM1 MTBE/TBA degradation pathway (Hristova et al. 2007) was isolated in stable isotope probe (SIP) microcosm experiments utilizing GAC from active, TBA degrading bioreactors in New York and California (Aslett et al. 2011). A recent microcosm study utilizing DNA-SIP, clone libraries and protein-SIP to characterize the MTBE degrading community identified M. petroleiphilum as dominant MTBE degrading organisms in sediments isolated from a contaminated site in the USA (Bastida et al. 2010). These studies confirm that M. petroleiphilium is a frequently present, active and important member of MTBE degrading communities.

The total biomass exiting the bioreactor in the effluent was not significantly higher than that of the background influent bacteria, which indicates that the bioreactor was effective at retaining much of the biomass. Studies of membrane bioreactors used to treat MTBE have found that high biomass retention is a critical property of bioreactors that have high rates of MTBE removal (Morrison et al. 2002). Retention of biomass is also desirable to reduce the introduction of elevated levels of active microbial biomass if effluents are discharged back into aquifers.

The self-seeded bioreactor at North Hollywood achieved highly efficient MTBE and TBA removal and with very short hydraulic retention times (20-30 min). The lack of acclimation period before the onset of MTBE removal, and the ability to operate at short HRTs, made this bioreactor system highly effective at treating large volumes of MTBE-impacted water. The very high biological removal efficiency of this bioreactor system may have been due, in part, to the continual input of MTBE-degrading organisms contained in the contaminated groundwater entering the bioreactor.

In our study, it took 17 weeks to maximize MTBE removal; it may have been possible to achieve a steady state in MTBE removal earlier if the bacteriostatic shock had been avoided. Previous studies of lab-scale MTBE bioreactors have relied on seeding of the bioreactors with lab-cultured MTBE-degrading bacteria or consortia and have reported significant lag phases before onset of MTBE degradation. Laboratory scale studies included tests of fluidized bed reactors (FBRs) with lag phases of 30 days (Pruden et al. 2003), or 20 days (Vainberg et al. 2002), a biotrickling filter with a long acclimation period (Fortin and Deshusses 1999), and a biomass concentrator reactor (BCR) with a 14 day acclimation period that had to be reseeded after a month of operation (Zein et al. 2004). In a field-scale study of an MTBE-treating BCR, an 8 week lag time preceded the onset of chemical removal (Zein et al. 2006).

Advantages of utilizing native bacteria include the fact that they are acclimated to site groundwater chemistry, are better adapted to the environmental stresses associated with the aquifer, and may be more efficient at colonizing the surfaces of the GAC than inocula grown up in laboratory suspensions. In addition, the native organisms were probably more capable of scavenging low levels of contaminants found in the influent to the bioreactor than would organisms grown up at the high substrate concentrations usually used to prepare inocula for 
bioaugmentation. Using native organisms also eliminates costs that would be associated with use of proprietary microbial inoculants in a remediation project. Additionally, and very importantly, gaining regulatory approval for re-injecting (re-using) valuable ground-water resources is much easier to attain when indigenous bacteria are used for the biological treatment of the contaminant.

A spike in effluent MTBE and corresponding drop in biomass in week 5, possibly due to hydrogen peroxide toxicity, provided an unanticipated opportunity to examine the relationship between MTBE removal and populations of M. petroleiphilum. The operational upset demonstrated a relationship between biomass and MTBE removal as well as the resilience of the native bacterial community to biological shocks. The resilience of MTBE degrading community to less severe perturbations has been demonstrated in a bench-scale bioreactor (Medella et al. 2011).

Although treatment of TBA, the first breakdown product of MTBE biodegradation, is essential to ensure complete removal of oxygenates in any field scale bioremediation system (Aslett et al. 2011), TBA accumulation is frequently observed in other MTBE-degrading bioreactors and at field sites (see e.g. (Morrison et al. 2002; Wilson et al. 2001). While low levels of TBA were detected in the influent to the North Hollywood bioreactor, effluent TBA was never detected throughout steady state operations, purportedly due to the capacity of resident bacteria to degrade TBA.

BTEX compounds have been shown to interfere with MTBE degradation in pure cultures of bacteria (Deeb et al. 2001), although these interactions may not develop in bioreactors populated with mixed bacterial consortia and with the potential to spatially segregate different metabolic processes (Pruden et al. 2003; Bianchi et al. 2009). Historically, BTEX and chlorinated compounds were present in the groundwater at the North Hollywood site (GeoTracker 2012), but by the start of the bioreactor trial, BTEX compounds were detected only sporadically and at low concentrations, and thus did not appear to interfere with the removal of MTBE. Similarly, occasional presence of low concentrations of chlorinated compounds in the influent had no apparent effect on MTBE degradation. No chlorinated compounds were detected in the bioreactor effluent during the course of the study.

To prevent degradation of existing water sources, the state of California implements strict controls for direct re-injection of treated water into aquifers. The requirements include reverse osmosis (RO) treatment, pathogen risk mitigation, TOC concentrations below 0.5 $\mathrm{mg} \mathrm{L}^{-1}$, and total nitrogen concentrations below $5 \mathrm{mg} \mathrm{N} \mathrm{L}^{-1}$ prior to re-injection CDPH (2011). A significant unanticipated outcome from implementation of our technology was the regulatory permission to return the water treated through this bioremediation process back into a California drinking water aquifer (CRWQCB 2005), Haley \& Aldrich, Inc., personal communication). The bioreactor removed $\sim 134 \mathrm{~kg}$ of MTBE, from 164 million L of water, with more than 113 million $\mathrm{L}$ of treated water re-injected back into the aquifer, resulting in substantial recovery of water resources. This study demonstrates that native bacteria may be equally or more effective than inoculated bacteria at colonizing and degrading MTBE in an ex-situ bioreactor and that use of native organisms may accelerate the transfer and implementation of MTBE bioremediation technologies in the field.

\section{Acknowledgments}

We are grateful to Kevin Feris for scientific and technical expertise and to Shanna Rompel and Cindy Wallace for laboratory support. This project was funded, in part, by the Tesoro Corporation, Inc., by the Environmental Protection Agency' Science to Achieve Results (STAR) fellowship program and by the National Institute of Environmental Health Sciences (NIEHS), NIH (grant number 5 P42 ES004699). Its contents are solely the responsibility of the authors and do not necessarily represent the official views of the Tesoro, EPA, NIEHS or NIH. 


\section{References}

Aslett D, Haas J, Hyman M. Identification of tertiary butyl alcohol (TBA)-utilizing organisms in BioGAC reactors using 13C-DNA stable isotope probing. Biodegradation. 2011; 22(5):961972.10.1007/s10532-011-9455-3 [PubMed: 21286787]

Bastida F, Rosell M, Franchini AG, Seifert J, Finsterbusch S, Jehmlich N, Jechalke S, Von Bergen M, Richnow HH. Elucidating MTBE degradation in a mixed consortium using a multidisciplinary approach. FEMS Microbiol Ecol. 2010; 73(2):370-384. [PubMed: 20491917]

Bayliss CE, Waites WM. The effect of hydrogen peroxide and ultraviolet irradiation on non-sporing bacteria. J Appl Microbiol. 1980; 48(3):417-422.10.1111/j.1365-2672.1980.tb01030.x

Bianchi E, Censabella I, Fascetti E. Aerobic biodegradation of MtBE in an upflow fixed bed reactor. J Chem Technol Biotechnol. 2009; 84(6):871-876.10.1002/jctb.2133

Bruns MA, Hanson JR, Mefford J, Scow KM. Isolate PM1 populations are dominant and novel methyl tert-butyl ether-degrading bacteria in compost biofilter enrichments. Environ Microbiol. 2001; 3(3): 220-225. [PubMed: 11321538]

CDPH. California Department of Public Health (CDPH); Sacramento: 2011. Groundwater recharge draft regulation. www.cdph.ca.gov/certlic/drinkingwater/Documents/Recharge/ DraftRechargeReg-2011-11-21.pdf [Accessed 5 Dec 2012]

Cheng ZW, Chen JM, Chen DZ, Zhang LL. Biodegradation of methyl tert-butyl ether in a bioreactor using Immobilized Methylibium petroleiphilum PM1 Cells. Water Air Soil Pollut. 2011; 214(1):5972.10.1007/s11270-010-0403-3

Christensen BE, Trønnes HN, Vollan K, Smidsrød O, Bakke R. Biofilm removal by low concentrations of hydrogen peroxide. Biofouling. 1990; 2(2):165-175.

CRWQCB. General waste discharge requirements for biologically activated, granular activated carbon (bioGAC) treated groundwater injections at former fast fuel site. 11051 Victory Boulevard, North Hollywood, California: 2005. (UST CASE FILE NO. 916061625, CI NO. 8907). http:// 63.199.216.6/larwqcb_new/permits/docs/8907_R4-2005-0030_RSC.pdf [Accessed 5 Dec 2012]

CRWQCB. [Accessed 6 Dec 2012] Termination of coverage under general waste discharge requirements former fast fuel site 11051 Victory Boulevard, California (A-I site) (UST FILE NO 916061625) (ORDER NO R4-2005-0030, SERIES NO 015, Cl-8907). 2009. http://63.199.216.6/ larwqcb_new/permits/docs/8907_R4-2005-0030_RSC.pdf

CRWQCB. 11051 Victory Blvd Closure Package. California Regional Water Quality Control Board; 2011. http://geotracker.waterboards.ca.gov/regulators/deliverable_documents/ 6213744938/11051VictoryBlvdClosurePackage.pdf [Accessed 6 Dec 2012]

Deeb RA, Hu HY, Hanson JR, Scow KM, Alvarez-Cohen L. Substrate interactions in BTEX and MTBE mixtures by an MTBE-degrading isolate. Environ Sci Technol. 2001; 35(2):312-317. [PubMed: 11347603]

Fortin NY, Deshusses MA. Treatment of methyl tert-butyl ether vapors in biotrickling filters. 1. Reactor startup, steady-state performance, and culture characteristics. Environ Sci Technol. 1999; 33(17):2980-2986.

Geotracker fast fuel facility (FORMER) (T0603702602). [Accessed 5 Dec 2012] State Water Resources Control Board. 2012. http://geotracker.waterboards.ca.gov/profile_report.asp? global_id=T0603702602

Hanson JR, Ackerman CE, Scow KM. Biodegradation of MTBE by bacterial strain PM1. Abstr Gen Meet Am Soc Microbiol. 1999; 99:552.

Hristova KR, Lutenegger CM, Scow KM. Detection and quantification of methyl tert-butyl etherdegrading strain PM1 by real-time TaqMan PCR. Appl Environ Microbiol. 2001; 67(11):51545160. [PubMed: 11679339]

Hristova K, Gebreyesus B, Mackay D, Scow KM. Naturally occurring bacteria similar to the methyl tert-butyl ether (MTBE)-degrading strain PM1 are present in MTBE-contaminated groundwater. Appl Environ Microbiol. 2003; 69(5):2616-2623. [PubMed: 12732529]

Hristova KR, Schmidt R, Chakicherla AY, Legler TC, Wu J, Chain PS, Scow KM, Kane SR. Comparative transcriptome analysis of Methylibium petroleiphilum PM1 exposed to the fuel- 
oxygenates methyl-tert-butyl ether and ethanol. Appl Environ Microbiol. 2007; 73:7347-7357. [PubMed: 17890343]

Kane SR, Beller HR, Legler TC, Koester CJ, Pinkart HC, Halden RU, Happel AM. Aerobic biodegradation of methyl tert-butyl ether by aquifer bacteria from leaking underground storage tank sites. Appl Environ Microbiol. 2001; 67(12):5824-5829. [PubMed: 11722940]

Kane SR, Chakicherla AY, Chain PSG, Schmidt R, Shin MW, Legler TC, Scow KM, Larimer FW, Lucas SM, Richardson PM, Hristova KR. Whole-genome analysis of methyl tert-butyl etherdegrading beta-proteobacterium Methylibium petroleiphilum PM1. J Bacteriol. 2007; 189(5): 1931-1945. [PubMed: 17158667]

Kharoune M, Pauss A, Lebeault JM. Aerobic biodegradation of an oxygenates mixture: ETBE, MTBE and TAME in an upflow fixed-bed reactor. Water Res. 2001; 35(7):1665-1674. [PubMed: 11329668]

Massol-Deya A, Weller R, Rios-Hernandez L, Zhou J, Hickey R, Tiedje J. Succession and convergence of biofilm communities in fixed-film reactors treating aromatic hydrocarbons in groundwater. Appl Environ Microbiol. 1997; 63(1):270-276. [PubMed: 8979355]

Medella A, Suidan MT, Venosa AD. Performance assessment of a new type of membrane bioreactor under steady state and transient operating conditions. J Environ Eng. 2011; 137(9):817-825.

Mehta, S. MTBE cleanup cost \$29 billion, study says. Los Angeles Times; 2001. 10/14/12

Morrison JR, Suidan MT, Venosa AD. Use of membrane bioreactor for biodegradation of MTBE in contaminated water. J Environ Eng. 2002; 128(9):836-841.10.1061/(asce)0733-9372

Nakatsu CH, Hristova KR, Hanada S, Meng XY, Hanson JR, Scow KM, Kamagata Y. Methylibium petroleiphilum PM1 gen. nov., sp nov., a novel methyl tert-butyl ether-degrading methylotroph of the Betaproteobacteria. Int J Syst Evol Microbiol. 2006; 56:983-989. [PubMed: 16627642]

Persson F, Heinicke G, Uhl W, Hedberg T, Hermansson M. Performance of direct biofiltration of surface water for reduction of biodegradable organic matter and biofilm formation potential. Environ Technol. 2006; 27(9):1037-1045. [PubMed: 17067130]

Pruden A, Suidan M, Venosa A, Wilson GJ. Biodegradation of methyl tert-butyl ether under various substrate conditions. Environ Sci Technol. 2001; 35(21):4235-4241. [PubMed: 11718336]

Pruden A, Sedran M, Suidan M, Venosa A. Biodegradation of MTBE and BTEX in an aerobic fluidized bed reactor. Water Sci Technol. 2003; 47(9):123-128. [PubMed: 12830950]

Schallenberg M, Kalff J, Rasmussen JB. Solutions to problems in enumerating sediment bacteria by direct counts. Appl Environ Microbiol. 1989; 55(5):1214-1219. [PubMed: 16347910]

Schmidt R, Battaglia V, Scow K, Kane S, Hristova KR. Involvement of a novel enzyme, MdpA, in methyl tert-butyl ether degradation in Methylibium petroleiphilum PM1. Appl Environ Microbiol. 2008; 74(21):6631-6638.10.1128/aem.01192-08 [PubMed: 18791002]

Slade, RC. Annual report Upper Los Angeles River Area Watermaster, 2011-2016 waer years edn. Upper Los Angeles River Area Watermaster; Los Angeles: 2012. Groundwater pumping and spreading plan for the upper Los Angeles river area (ULARA) Los Angeles county, California.

Stringfellow WT, Oh KC. Initiation of MTBE biotreatment in fluidized-bed bioreactors. J Environ Eng. 2002; $128: 852$.

Sweet F, Kauffman M, Pellerin T, Espy D, Mills M. An Estimate of the National cost for Remediation of MTBE releases from existing leaking underground storage tank sites. 2010:12.

Vainberg S, Togna AP, Sutton PM, Steffan RJ. Treatment of MTBE-contaminated water in fluidized bed bioreactor. J Environ Eng. 2002; 128(9):842-851.10.1061/(asce)0733-9372

Velji M, Albright L. Microscopic enumeration of attached marine bacteria of seawater, marine sediment, fecal matter, and kelp blade samples following pyrophosphate and ultrasound treatments. Can J Microbiol. 1986; 32(2):121-126.

Wilson GJ, Richter AP, Suidan MT, Venosa AD. Aerobic biodegradation of gasoline oxygenates MTBE and TBA. Water Sci Technol. 2001; 43(2):277-284. [PubMed: 11380191]

Wilson G, Pruden A, Suidan M, Venosa A. Biodegradation kinetics of MTBE in laboratory batch and continuous flow reactors. J Environ Eng. 2002; 128:824.

Zein MM, Suidan MT, Venosa AD. MtBE biodegradation in a gravity flow, high-biomass retaining bioreactor. Environ Sci Technol. 2004; 38(12):3449-3456.10.1021/es030652y [PubMed: 15260347] 
Zein MM, Suidan MT, Venosa AD. Bioremediation of groundwater contaminated with gasoline hydrocarbons and oxygenates using a membrane-based reactor. Environ Sci Technol. 2006; 40(6): 1997-2003.10.1021/es051593m [PubMed: 16570627] 


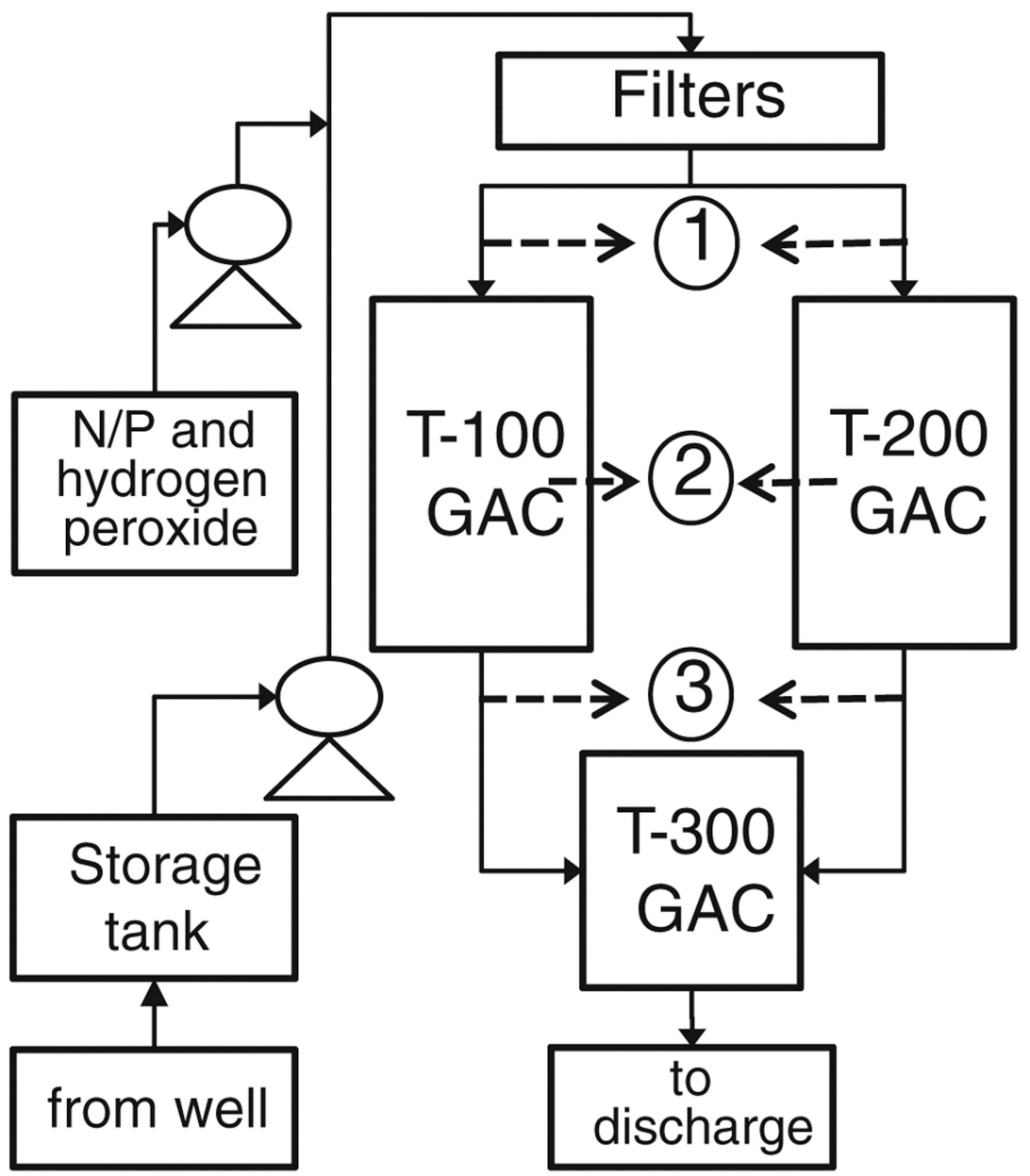

Fig. 1.

Schematic of bioreactor. MTBE-contaminated ground-water was pumped through two primary treatment tanks (T100 and T200) and then through a third polishing tank (T300). Samples were collected at the inlet (1), mid section (2), and outlet (3) of tanks T100 and T200 as indicated by dashed lines 


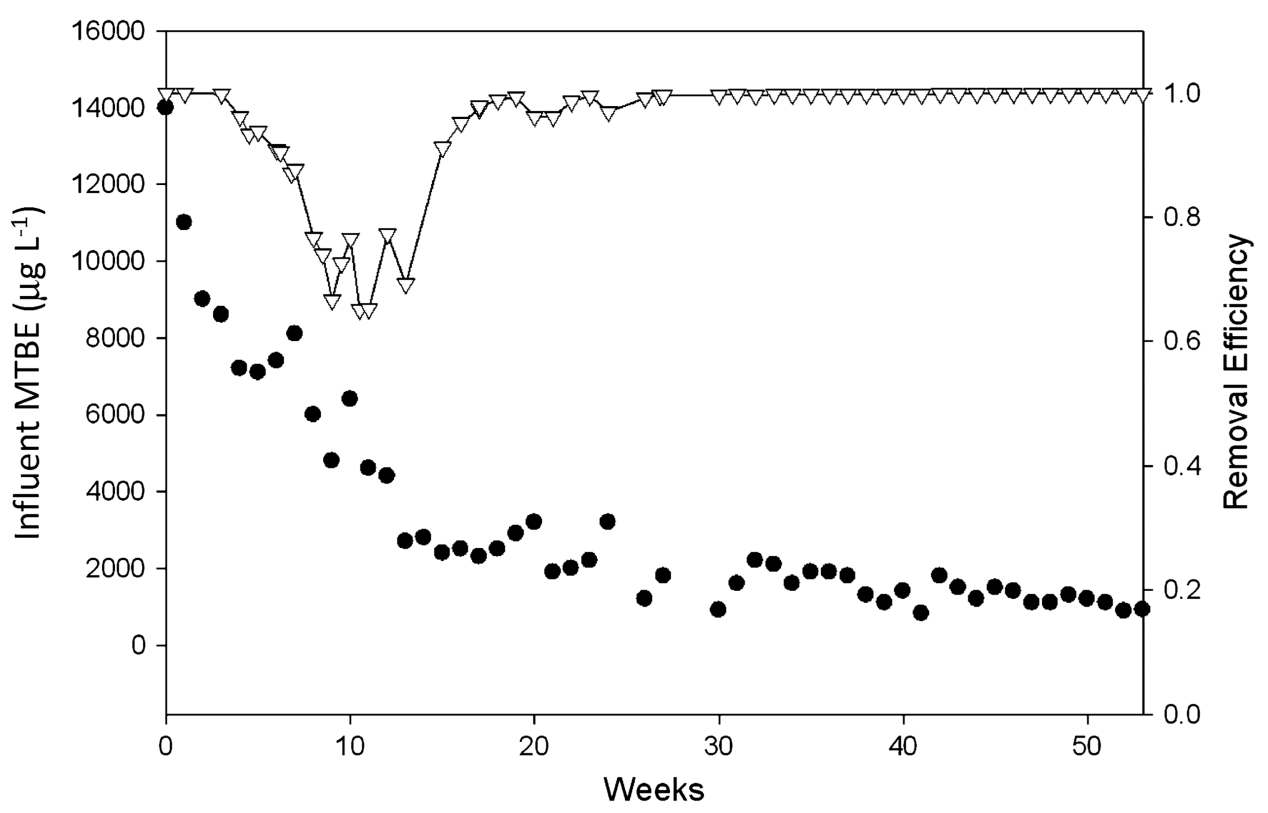

Fig. 2.

MTBE concentration in the inlet to the primary tanks (telephone) and removal efficiency of T200 (inverse triangle). Tanks T100 and T200 were virtually identical in removal efficiencies 


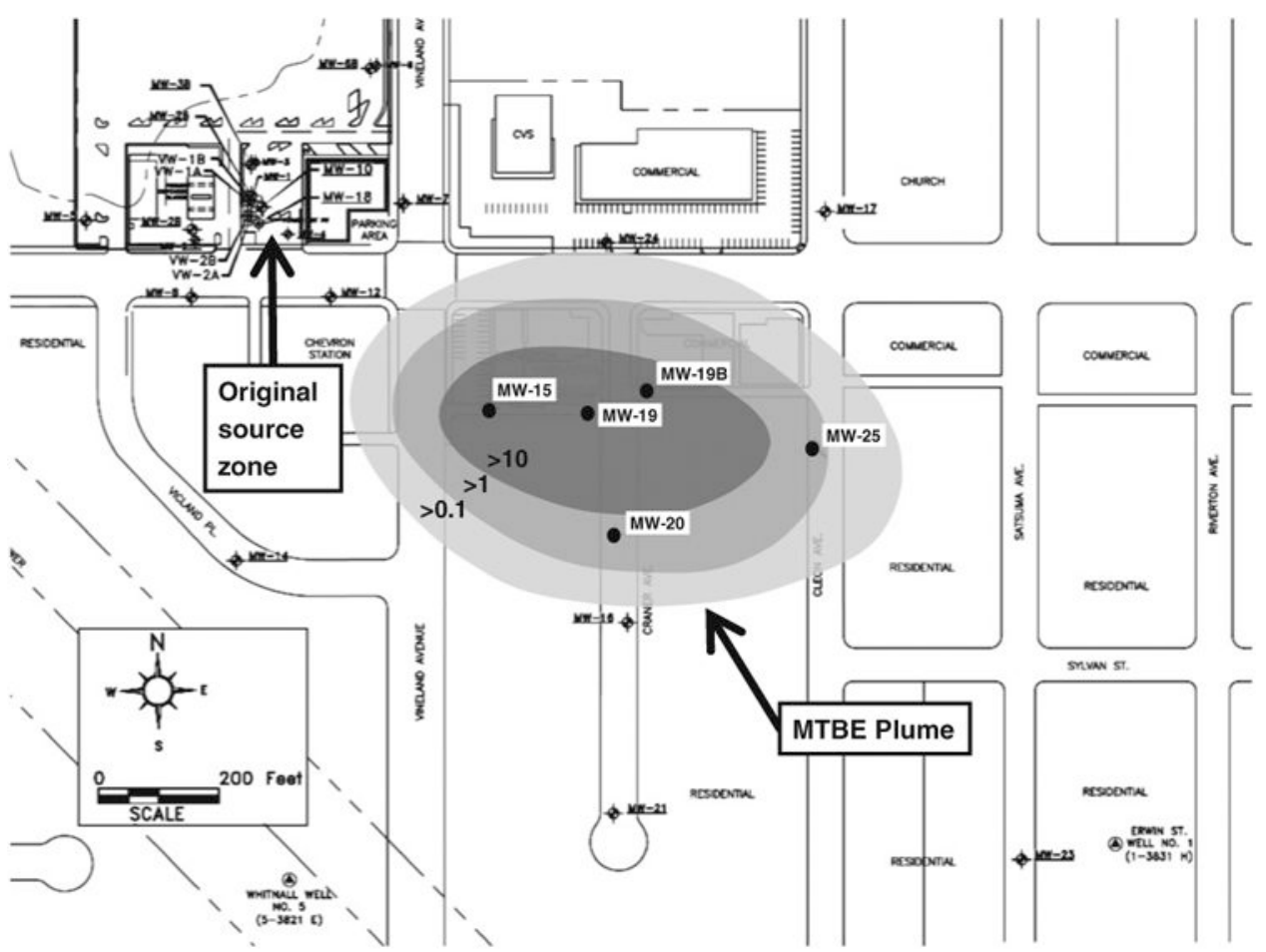

Fig. 3.

MTBE Isoconcentration map, week 1. Groundwater treated by the bioreactor was pumped from MW-15 and MW-19. Isoconcentration values for MTBE are in $\mathrm{m} \mathrm{L}^{-1}$ 


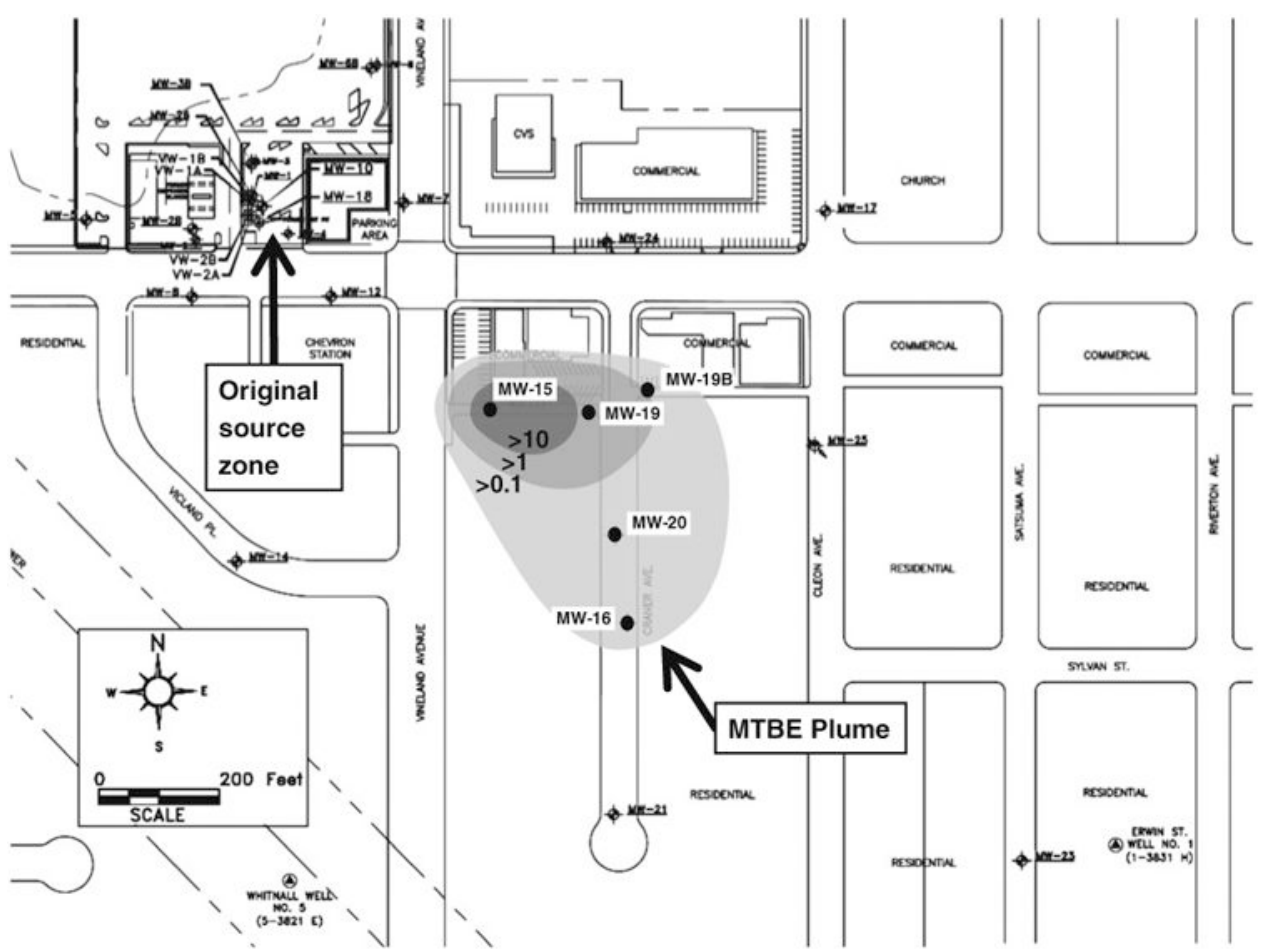

Fig. 4.

MTBE Isoconcentration map, week 53. Groundwater treated by the bioreactor was pumped from MW-15 and MW-19. Isoconentration values for MTBE are in $\mathrm{mg} \mathrm{L}^{-1}$ 


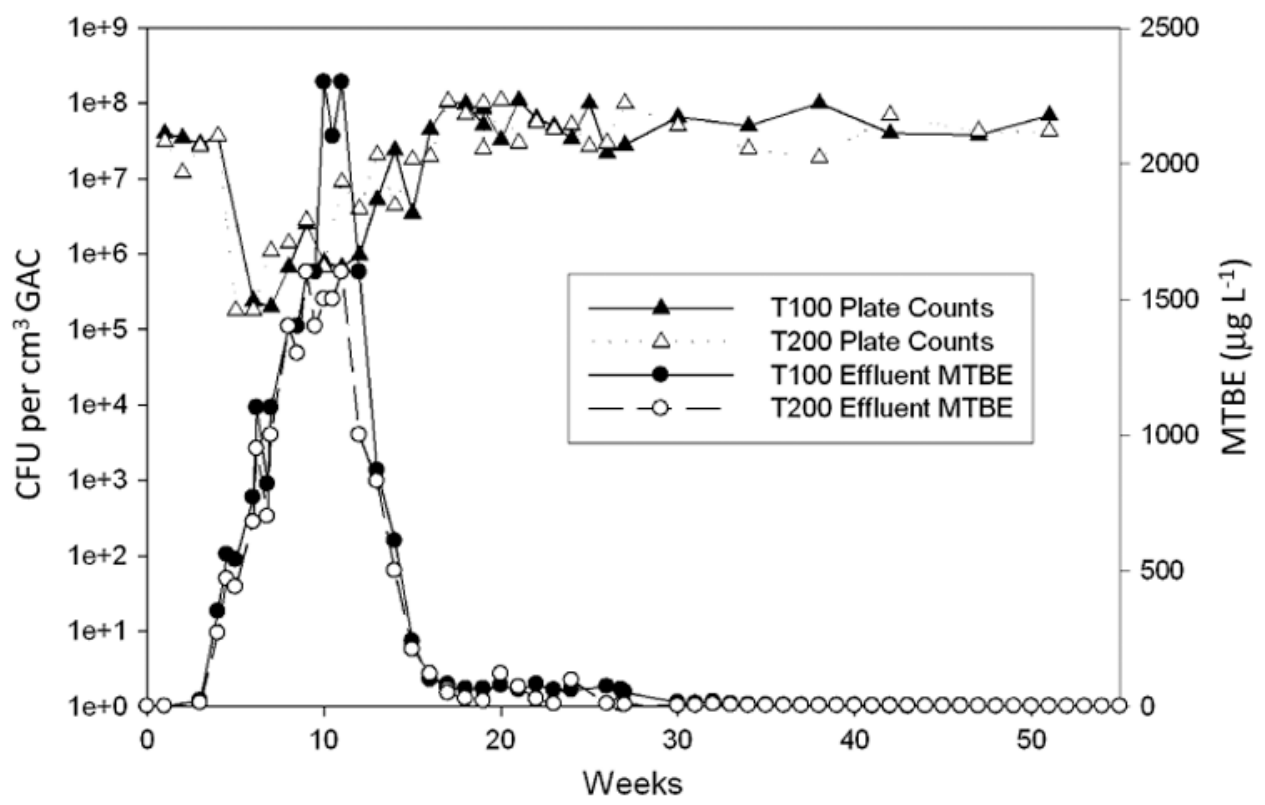

Fig. 5. Total attached bacteria by viable plate counts (filled trianglelopen triangle) and effluent MTBE (maltese cross/telephone) within primary tanks T100 and T200 over the first 52 weeks 


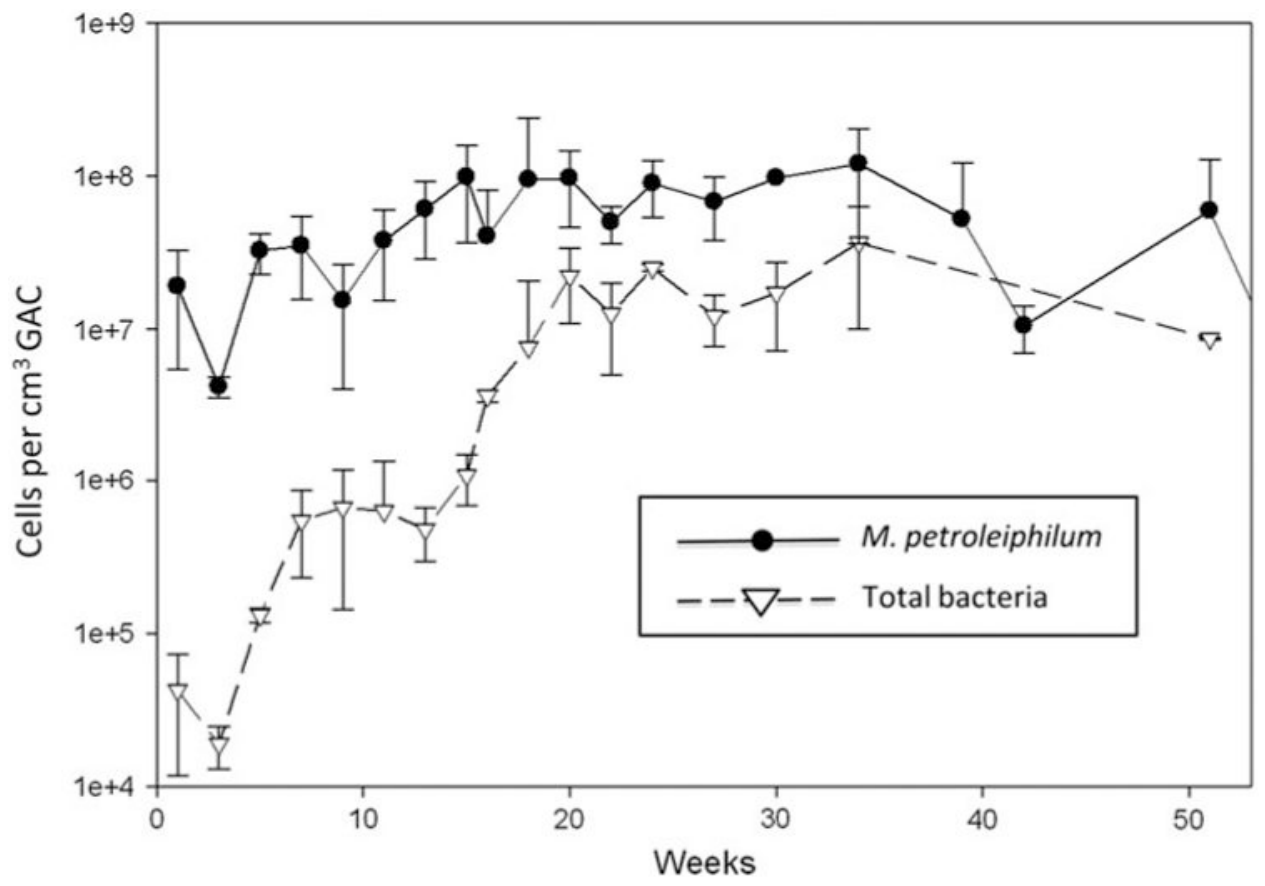

Fig. 6. Total attached bacteria (maltese cross) and attached M. petroleiphilum (inverse triangle) by qPCR in primary tank T200 over the course of 52 weeks 
Table 1

Pilot-scale bioreactor parameters

\begin{tabular}{|c|c|c|c|}
\hline \multirow[t]{2}{*}{ Parameters } & \multirow[t]{2}{*}{ Units } & \multicolumn{2}{|l|}{ Bioreactor } \\
\hline & & T100 and T200 & T300 \\
\hline \multicolumn{4}{|l|}{ Flow rates and mass loading } \\
\hline Max VOC mass loading & $\mathrm{g} \min ^{-1}$ & 1.5 & NA \\
\hline Recycle flow rate & $\mathrm{L} \min ^{-1}$ & $18.9-75.7$ & NA \\
\hline Max hydraulic loading & $\mathrm{L} \min ^{-1}$ & 75.7 & 75.7 \\
\hline Max hydraulic residence time (@18.9 $\mathrm{L} \mathrm{min}^{-1}$ ) & $\min$ & 34.9 & 57.4 \\
\hline Min hydraulic residence time (@75.7 L min ${ }^{-1}$ ) & $\min$ & 21.8 & 14.3 \\
\hline \multicolumn{4}{|l|}{ Dimensions } \\
\hline Tank diameter & $\mathrm{m}$ & 1.2 & 1.2 \\
\hline Tank height & $\mathrm{m}$ & 2.2 & 1.4 \\
\hline Tank capacity & $\mathrm{L}$ & 2548 & 1580 \\
\hline \multicolumn{4}{|l|}{ Media } \\
\hline Media type & - & GAC & GAC \\
\hline Effective size & $\mathrm{mm}$ & $0.6-0.85$ & $0.6-0.85$ \\
\hline Media weight (total per treatment tank) & $\mathrm{kg}$ & 794 & 454 \\
\hline Water & $\mathrm{L}$ & 1650 & 1084 \\
\hline \multicolumn{4}{|l|}{ Nutrient stock solutions } \\
\hline Hydrogen peroxide & $\mathrm{g} \mathrm{L}^{-1}$ & 206.25 & NA \\
\hline Sodium nitrate & $\mathrm{g} \mathrm{L}^{-1}$ & 45.17 & NA \\
\hline Monosodium phosphate & $\mathrm{g} \mathrm{L}^{-1}$ & 5.65 & NA \\
\hline \multicolumn{4}{|l|}{ Influent nutrient concentrations } \\
\hline Hydrogen peroxide & $\mathrm{mg} \mathrm{L}^{-1}$ & $25-50$ & NA \\
\hline Sodium nitrate & $\mathrm{mg} \mathrm{L}^{-1}$ & $\sim 100$ & NA \\
\hline Monosodium phosphate & $\mathrm{mg} \mathrm{L}^{-1}$ & ND & NA \\
\hline \multicolumn{4}{|l|}{ Water parameters } \\
\hline Temp & ${ }^{\circ} \mathrm{C}$ & $15-18$ & $15-18$ \\
\hline $\mathrm{pH}$ & & $6.7-7.2$ & $6.7-7.2$ \\
\hline Target DO (T100, T200 effluent) & $\mathrm{mg} \mathrm{L}^{-1}$ & $8-10$ & - \\
\hline Period of treatment & weeks & 52 & NA \\
\hline Total MTBE removed & $\mathrm{kg}$ & 115.2 & NA \\
\hline Max MTBE removal rate & $\mu \mathrm{gMTBE} \mathrm{cm}^{-3} \mathrm{day}^{-1}$ & 391 & NA \\
\hline Total GW volume treated & $\mathrm{L}$ & $2.8 \times 10^{7}$ & NA \\
\hline
\end{tabular}

NA not applicable, T300 typically had no loading, All of the treatment (after acclimation period) was done by T100 and T200, ND - not detected 
Table 2

Summary of performance parameters for a field scale bioreactor treating MTBE

\begin{tabular}{lllll}
\hline & Removal efficiency $(\%)$ & Effluent MTBE $(\mu \mathbf{g} \mathbf{L})$ & $\begin{array}{l}\text { Removal rat }(\mu \mathrm{g} \text { MTBE cm } \\
\left.\mathbf{d a y}^{-\mathbf{- 1}}\right)\end{array}$ & $\begin{array}{l}\text { Mass removed in 52 weeks } \\
(\mathbf{k g})\end{array}$ \\
\hline T100 & 99 & $34(n=52)$ & 391 & 57.9 \\
T200 & 99.5 & $23(n=52)$ & 333 & 57.3 \\
Final discharge & 99.9 & $1.5(n=33)$ & $\mathrm{NR}$ & $\mathrm{NR}$ \\
\hline
\end{tabular}


Table 3

Summary of total bacterial and $M$. petroleiphilum densities by plate count and by quantitative PCR in both attached (treatment tanks) and planktonic (treatment tanks, influent, effluent) phases

\begin{tabular}{lllll}
\hline & Influent & Treatment tanks-attached & Treatment tanks-planktonic & Effluent \\
\hline Plate counts & $4.1 \times 10^{3}(n=23)$ & $4.9 \times 10^{7}\left( \pm 3.0 \times 10^{6} ; n=36\right)$ & $2.7 \times 10^{6}\left( \pm 1.5 \times 10^{5} ; n=36\right)$ & $1.5 \times 10^{4}(n=19)$ \\
Q-PCR (total bacteria) & $3.1 \times 10^{5}(n=14)$ & $8.5 \times 10^{7}\left( \pm 9.0 \times 10^{6} ; n=26\right)$ & $9.5 \times 10^{6}\left( \pm 3.5 \times 10^{6} ; n=26\right)$ & $8.0 \times 10^{5}(n=13)$ \\
Q-PCR (M. petroleiphilum) & $5.9 \times 10^{3}(n=16)$ & $1.3 \times 10^{7}\left( \pm 4.6 \times 10^{6} ; n=16\right)$ & $4.6 \times 10^{4}\left( \pm 1.5 \times 10^{4} ; n=14\right)$ & $2.0 \times 10^{4}(n=16)$ \\
\hline
\end{tabular}

Densities are reported as CFU (plate counts) or cells (qPCR) per ml (planktonic) or per $\mathrm{cm}^{3}$ (attached). Bacterial densities in the treatment tanks are steady state concentrations ( $>17$ weeks). \pm values refer to the variation between the averages of T100 and T200 